University of Nebraska - Lincoln

DigitalCommons@University of Nebraska - Lincoln

Faculty Publications, Department of Psychology

Psychology, Department of

2011

\title{
Holding Parents Responsible: Is Vicarious Responsibility the Public's Answer to Juvenile Crime?
}

\author{
Eve M. Brank \\ University of Nebraska-Lincoln, ebrank2@unl.edu \\ Edie Greene \\ University of Colorado at Colorado Springs, egreene@uccs.edu \\ Katherine Hochevar \\ Colorado Department of Corrections
}

Follow this and additional works at: https://digitalcommons.unl.edu/psychfacpub

Part of the Juvenile Law Commons, Law and Psychology Commons, and the Psychology Commons

Brank, Eve M.; Greene, Edie; and Hochevar, Katherine, "Holding Parents Responsible: Is Vicarious Responsibility the Public's Answer to Juvenile Crime?" (2011). Faculty Publications, Department of Psychology. 976.

https://digitalcommons.unl.edu/psychfacpub/976

This Article is brought to you for free and open access by the Psychology, Department of at DigitalCommons@University of Nebraska - Lincoln. It has been accepted for inclusion in Faculty Publications, Department of Psychology by an authorized administrator of DigitalCommons@University of Nebraska - Lincoln. 


\title{
Holding Parents Responsible: Is Vicarious Responsibility the Public's Answer to Juvenile Crime?
}

\author{
Eve M. Brank, ${ }^{1}$ Edie Greene ${ }^{2}$ and Katherine Hochevar ${ }^{3}$ \\ 1. Department of Psychology, University of Nebraska-Lincoln, Lincoln, Nebraska, USA \\ 2. Department of Psychology, University of Colorado at Colorado Springs, Colorado Springs, \\ Colorado, USA \\ 3. Colorado Department of Corrections
}

Corresponding author - Eve M. Brank, P.O. Box 880308, Lincoln, NE 68588-0308, email ebrank2@unl.edu

\begin{abstract}
Parental responsibility laws hold parents accountable for the delinquent behaviors of their children even when parents' actions are not the direct cause of an offense. Despite the prevalence of these laws, we know little about their perceived fairness. Is it reasonable to make parents vicariously responsible for outcomes they could not have foreseen and, if so, under what circumstances? Our series of three studies addressed those questions by systematically examining the impact of various situational and dispositional factors on public opinions regarding parental responsibility. Respondents attributed most of the responsibility for a crime to the child, and attributions of responsibility to the parents varied as a function of the child's age. Case characteristics including the type of crime committed and the described parents' actions versus inactions did not consistently influence responsibility attributions. We conclude that people feel rather lukewarm about the notion of vicarious parental responsibility and this indifference may be related to issues surrounding the laws' enforcement.
\end{abstract}

Keywords: vicarious responsibility, parental responsibility, juvenile delinquency

All across the United States, cities and states have laws that penalize parents for the delinquent behaviors of their children. For example, an ordinance in Wilmington, Delaware 
holds parents responsible for their minor's actions when the minor is out past the city curfew (Curfew for minors, 2009). In Jacksonville, Florida, parents are ordered to pay for any graffiti damage committed by their minor son or daughter (Graffiti prohibited, 2009). Parents of minors in Indian Shores, Florida, are responsible for ensuring that their children's pets are not let loose in town (Restraint required, 2009). In Detroit, Michigan, parents have the broad "continuous duty" to prevent their child from "committing any delinquent act" (Parental duties, 2009).

Although many jurisdictions have enacted such statutes and ordinances, we know rather little about whether people favor attributing this form of vicarious responsibility to parents. Research on public support of these laws deserves further attention for at least three reasons. First, public support of social issues can motivate the imposition of new laws and revision of existing laws. In fact, public support can be a proximate cause of policy changes (Page \& Shapiro, 1983); witness the current trend toward imposing harsh immigration laws in the southwestern United States. Although no public opinion data existed when initial parental responsibility laws were enacted, one can now gauge whether the laws command public support. Previous studies have shown only lukewarm endorsement, at least as measured by global attitudes. We undertake a closer look at the circumstances that influence public opinion about parental responsibility.

Second, public support can also influence enforcement of current laws (Warr, Meier, \& Erickson, 1983). Especially when diminished resources result in the selective enforcement of existing laws, public officials will explicitly and implicitly opt to enforce those laws they believe are broadly supported by the public. Thus, assessing public opinion can be useful for explaining levels of enforcement. We also undertake that task in our current studies.

Third, it is useful to gauge public opinion because those opinions are related to legal compliance; people are more likely to obey laws they perceive as legitimate and fair (Tyler, 2006). Thus, it may be particularly important to examine how parents of teenagers view parental responsibility laws because their beliefs may guide the parents' behavior. The laws' proponents may have assumed that fearing legal responsibility, parents would exercise more control over their children's behavior. But if parents deride these laws, they will feel little compulsion to do so. We explore these possibilities by examining beliefs about parental responsibility in parents of teens.

In general, people are willing to hold accountable individuals whose actions are causally related to a negative outcome, even if those actions were not the proximate cause. Does this generality extend to parents of delinquent youth? Should parents be held to answer for the actions of their children? To what extent are characteristics of the juvenile, the crime, and the parents' conduct relevant to that question? To what extent do beliefs vary as a function of respondents' characteristics? We address those questions by assessing whether case characteristics - including age of the child, nature of the crime, and behavior of the parents-and respondent characteristics-including gender and parental status-influence thoughts about the appropriateness of laws that make parents vicariously responsible for their children's actions.

We begin by examining the notions of direct and vicarious responsibility. Next, we examine the legal context in which parents can be held responsible for their children's behaviors and describe previous research on the public's views of these laws. Finally, we use 
our series of three studies to focus on how case, offender, and respondent characteristics influence attitudes toward parental responsibility.

\section{Direct and Vicarious Responsibility}

Responsibility permeates everyday life (Cartwright, 2006) and the law (Hamilton, 1978) in the United States and beyond (Sanders \& Hamilton, 1987). Attributions of responsibility are associated with notions of causality, moral accountability, and culpability when someone creates, fosters, or fails to inhibit an event (Cartwright, 2006). According to philosophers, responsibility occurs in three different contexts: (1) in describing someone as a responsible person-meaning that there is something morally favorable about this person; (2) as an expectation that someone is responsible for something yet to happen - this person will do what needs to be done; and (3) as an attribution that someone was responsible for a past action, not necessarily that the person caused the action, but that it is appropriate to hold the person responsible for that action (Frankena, 1963). Our current studies are related to this third situation.

Responsibility is the bond that connects an actor to an event and to the relevant rules that govern conduct (Schlenker, Britt, Pennington, Murphy, \& Doherty, 1994). When we make attributions of responsibility, we compare what a person did to what the person was supposed to do in light of her role (Hamilton, 1978). That is, roles people have dictate their obligations and the liability associated with failing to meet those obligations. Different roles demand different standards of accountability and impose different penalties for failure to meet those standards.

Most psychological research on assigning responsibility relates to direct attributions of responsibility in which the person who actually caused the action or created the harm is deemed responsible (Shultz, Jaggi, \& Scheiffer, 1987). Yet there are instances when responsibility is attributed to someone other than the person who directly caused the harm (Feinberg, 1968). Sometimes referred to as vicarious responsibility or collective responsibility (Fincham \& Jaspars, 1980; Lickel, Schmader, \& Hamilton, 2003), this concept implies that people assign responsibility to those who were not directly related to the event (Denson, Lickel, Curtis, Stenstrom, \& Ames, 2006). Heider's "most primitive level" of responsibility attribution is one of vicarious responsibility such that a person is held responsible for any effect that is somehow connected to him (1958, p. 113) even though the person did not possess personal control over the behavior (Schlenker et al., 1994). Studies of harm and moral blame suggest that individuals are indeed blamed for consequences they could not foresee or did not intend but that were set in motion by their conduct (Alicke, 1992). But Greene and Darley (1998) have shown that although people can attribute responsibility to multiple causal agents, they assign less responsibility to agents whose connection to an action is more remote or indirect.

Testing hypotheses derived from the literature on moral philosophy, Shultz et al. (1987) presented stories in which one person caused harm to another and a third person was indirectly implicated. The researchers varied the third person's control over the wrongdoer's harm-producing behavior (the third person either had control or did not) and the third person's social standing in relation to the wrongdoer (either superior or equal). Ratings of 
both causal and moral responsibility of the third person were higher when that person had control over the wrongdoer and was in a position of social superiority, perhaps because in those situations, the third person could have intervened to prevent the harm from occurring. These findings suggest that a person who is in some way superior to another and who is able to control another's behavior may be causally implicated in any harm created by that individual.

These ideas were tested in a study that evaluated whether family and friends of juvenile offenders would be deemed vicariously responsible for the juveniles' conduct (Lickel et al., 2003). Lickel and colleagues focused on the parents and other persons potentially involved in the Columbine High School shooting. A few days after gunmen Eric Harris and Dylan Klebold led a massacre on their high school in Littleton, Colorado, Lickel and his colleagues asked members of the public about parent and peer responsibility for the school shootings. Both parents and peers were deemed vicariously responsible; parents were seen as responsible for reasons of omission (failing to act in a way that could have prevented the shooting), whereas peers were seen as responsible for reasons of commission (as members of the Trench Coat Mafia, they shared goals with the perpetrators).

These findings relate to a specific, particularly heinous crime in which 15 people (including the gunmen) were killed and 24 people were injured. The question remains whether parents are generally seen as responsible for the actions of their children (Denson et al., 2006) and whether case characteristics, including the juvenile's age and the nature of the crime, play a role in such opinions. Another important case characteristic alluded to by Lickel et al. (2003), concerns whether the parents committed or omitted a particular action that led to the juvenile's misconduct. In the context of parental responsibility laws, parents can be held responsible whether their own conduct involved acts of commission or omission. Thus, we ask in the current research whether people will hold parents vicariously responsible, regardless of whether the parent actively contributed to the juvenile's crime or simply failed to prevent it (i.e., a commission vs. an omission).

In other settings, acts of omission are consistently judged as less immoral or less bad than acts of commission (Spranca, Minsk, \& Baron, 1991). Called the omission bias, people perceive the outcome of an omission as less intentional than the outcome of a commission, which leads to evaluating the behavior and the person less negatively (Kordes-de Vaal, 1996). In studies examining the omission bias, the omission or commission always leads directly to the outcome, which contributes to the perception that acts of commission are more intentional and therefore that the actors are more responsible (Zeelenberg, van der Pligt, \& de Vries, 2000). One objective of the current research was to examine whether that sentiment also applies to beliefs about the vicarious responsibility of parents for the delinquent acts of their children.

\section{The Nature of Parental Responsibility Laws}

The idea that parents should be legally responsible for the actions of their children is certainly not new. Under common law principles, parents may be held civilly liable for the tortuous actions of their children. Such a case would be difficult to prove because the plaintiff would have to establish the requisite "duty, breach, causation, and damages" (Ihrie, 
1996). In other words, the plaintiff would have to prove not that the child's action caused the damages but that there was a causal connection between the parent's negligence and the harm suffered. The mere fact of a parent-child relationship does not satisfy the causal connection; rather there must be some clear connection between the parents' action (or inaction) and the resulting harmful act by the child (Tomaszewski, 2005).

As an alternative to the common law negligence suit against a parent, states in the United States have statutorily defined when parents can be held liable for their child's actions. In fact, all 50 states have statutorily defined parental responsibility laws that make parents either civilly or criminally liable for the acts of their children (Brank, Kucera, \& Hays, 2005). As shown in Table 1, three main forms exist-civil liability, criminal liability, and general involvement statutes.

Table 1. Descriptions of Parental Responsibility Laws

\begin{tabular}{|c|c|c|}
\hline Type & Description & Example law \\
\hline Civil liability & $\begin{array}{l}\text { Plaintiff may bring a } \\
\text { case against a parent of } \\
\text { a child who commits an } \\
\text { act resulting in property } \\
\text { damage or personal in- } \\
\text { jury the child }\end{array}$ & $\begin{array}{l}\text { Idaho } \S 6-210 \text {, "Any person shall be entitled to recover } \\
\text { damages in an amount not to exceed two thousand five } \\
\text { hundred dollars }(\$ 2,500) \text { in a court of competent juris- } \\
\text { diction from the parents of any minor, under the age of } \\
\text { eighteen }(18) \text { years, living with the parents, who shall } \\
\text { willfully cause economic loss to such person..." }\end{array}$ \\
\hline $\begin{array}{l}\text { Criminal liability/ } \\
\text { Contributing to the } \\
\text { delinquency }\end{array}$ & $\begin{array}{l}\text { State can bring a case } \\
\text { against a parent (or } \\
\text { other adult) who con- } \\
\text { tributes to the delin- } \\
\text { quency of a minor }\end{array}$ & $\begin{array}{l}\text { Mississippi } \S 97-5-39, \text { "... any parent ... who willfully } \\
\text { commits any act or omits the performance of any duty, } \\
\text { which act or omission contributes to or tends to contrib- } \\
\text { ute to the neglect or delinquency of any child . . shall } \\
\text { be guilty of a misdemeanor, and upon conviction shall } \\
\text { be punished by a fine not to exceed One Thousand Dol- } \\
\text { lars }(\$ 1,000.00) \text {, or by imprisonment not to exceed one } \\
\text { (1) year in jail, or by both such fine and imprisonment." }\end{array}$ \\
\hline General involvement & $\begin{array}{l}\text { State can require parent } \\
\text { to participate in the ju- } \\
\text { venile's delinquency } \\
\text { case }\end{array}$ & $\begin{array}{l}\text { Nebraska } \S 43-290 \text {, "to promote parental responsibility } \\
\text { and to provide for the most equitable use and availabil- } \\
\text { ity of public money ... the court may order and decree } \\
\text { that the parent shall pay, in such manner as the court } \\
\text { may direct, a reasonable sum that will cover in whole or } \\
\text { part the support, study, and treatment of the juvenile, } \\
\text { which amount ordered paid shall be the extent of the } \\
\text { liability of the parent." }\end{array}$ \\
\hline
\end{tabular}

Under civil liability, the most widely used of the three and the direct answer to the common law tort case, a plaintiff may bring a case against the parents for property damage or personal injury. A case under one of these statutes would be easy to prove (most are written in strict liability terms); however, the statutes generally have fairly low recovery limits (Brank et al., 2005).

Under criminal liability, the guardian or other adult may be held criminally responsible for contributing to the delinquency of a minor. These laws apply when an adult does some action that encourages delinquent behavior by a child.

General involvement statutes are based upon legislative efforts to make parents more involved in the juvenile court process and include such things as requiring the parents to 
pay for court costs, restitution, and treatment, and to participate in the juvenile's case (Brank et al., 2005; Davies \& Davidson, 2001). Failure to comply with the parental involvement requirements can lead to more punitive sanctions in some states (Brank, Hays, \& Weisz, 2004; Tyler \& Segady, 2000).

The general involvement statutes in the United States are based on the premise of vicarious responsibility. No parental mens rea is required, and the underlying principle is that the youthful misdeeds can be traced in some way to the parents (Harris, 2006). The legislative intents suggest a desire to have the parents instill in their children a respect for the law, but a clear legislative goal is often lacking or undocumented (Brank et al., 2005). Harris (2006) speculates that the laws are more symbolic than they are pragmatic.

Certainly, criminological research supports the idea that children's behaviors can be linked to parental actions or inactions. For instance, research has consistently demonstrated that children who participate in illegal activities often have poor relationships with their parents or come from homes where parents are not actively involved in the children's lives (Simourd \& Andrews, 1994). The operative word though is often. Many instances exist where law-abiding juveniles have difficult home situations and delinquent juveniles have stable homes. This unpredictability may play a role in public opinion regarding parental responsibility and in the ways the laws are enforced.

\section{Public Support of Parental Responsibility Laws}

National polls show only moderate public support for parental responsibility statutes. One national survey found that only half $(49 \%)$ of those sampled thought that irresponsible parents were to blame for the difficulties facing children (Public Agenda Online, 1999). A national Gallup Organization telephone survey found that people's attitudes toward parental responsibility were quite supportive when the question asked about a parent's responsibility in addition to that of the juvenile but less supportive when the questions asked about blaming and punishing only the parents (Brank \& Weisz, 2004). Together, the results of these national surveys indicate that the public is unwilling to place sole responsibility on the parents when a juvenile commits a crime.

This reluctance to find parents wholly responsible was apparent in a series of studies that found significant differences between global and specific attitudes about a described juvenile (Brank et al., 2005). Global attitudes like those measured in the national surveys were consistently more supportive of parental responsibility than were specific attitudes that were based on a described juvenile's case. Even juveniles do not believe their parents are responsible for their delinquent behaviors. Brank and Lane (2008) interviewed juveniles in a post-adjudication residential facility and found that most of the juveniles did not think their parents were responsible for their delinquency. White and her colleagues employed self-referencing vignettes with parents in Australia (White, 2005; White, Augoustinos, \& Taplin, 2007) and found that participants attributed less responsibility to the parents when the juvenile was described as older and knowing right from wrong (White et al., 2007).

Public opinion concerning the vicarious responsibility of parents will obviously be influenced by the constellation of factors in a specific case. In general, we know that people 
attribute more responsibility to juveniles who commit more serious offenses (Samuel \& Mould, 1986), have a prior record (Applegate, Cullen, Turner, \& Sundt, 1996; Roberts, 1997), are older (Ghetti \& Redlich, 2001), are African American (Leonard, Pope, \& Feyerherm, 1995), and are male (Mustard, 2001). We do not know about the factors that influence attributions of vicarious responsibility to parents. Thus, we examine the role of various case and respondent factors in our three studies.

\section{The Current Research}

Previous research on opinions about parental responsibility were limited because they relied either on college student samples or national public opinion polling with few questions about parental responsibility and because they provided few contextual details about the juvenile, the parents, or their respective behaviors. The current series of studies used vignette methodology that broadened the types of case characteristics we could examine and allowed us to assess whether specific parental behaviors, namely their actions and inactions, influence public perceptions about parental responsibility. It also allowed us to determine whether parents think of these issues differently than nonparents. We began by determining which case and offender factors were most important to this analysis.

\section{Study One: Determining the Importance of Case and Offender Characteristics}

The first study employed a fractional factorial design to establish which case and offender characteristics would be most useful to the more substantive studies that followed. Using vignette methodology, we systematically manipulated the case characteristics of offense seriousness, premeditation, and type of crime, and the offender characteristics of race, age, gender, and prior criminal activity. We measured general and specific attitudes about the parents' responsibility.

\section{Methods}

\section{Participants}

The sample consisted of 246 participants ( $41 \%$ male) from a large southeastern university. Five participants were removed because they were parents $(n=2)^{1}$ or did not answer the manipulation check questions correctly $(n=3)$. Participants' ages ranged from 18 to 37 with a mean age of $20.78(S D=2.25)$. The majority of the sample was White $(72.2 \%)$. Students participated in the study on a voluntary basis and were not compensated for their participation.

Design

A $2^{5+2}$ fractional factorial design was employed to examine seven independent variables within a vignette about a juvenile crime. A fractional factorial design is a useful technique to employ when the inquiry area does not have extensive prior research or a coherent theory from which to guide experimental choices (Stolle, Robbennolt, Patry, \& Penrod, 2002). The seven manipulated variables included four offender characteristics: gender (male or 
female), age (9 or 15), race (White or Black), and previous record (yes or no); and three case-related characteristics: seriousness of offense (high or low), type of crime (person or property crime), and premeditation (yes or no). By utilizing the fractional factorial design, we had 32 different vignettes with approximately eight participants per cell. Because we used the fractional factorial design, we had 123 participants per cell for main effects analyses.

\section{Materials}

Scenarios. The one-page scenarios described a juvenile referred to as J.T.R. The crime was described as either an assault during a mugging or vandalism to a gas station (person or property crime, respectively). We manipulated seriousness with the crime outcomes. High seriousness for mugging resulted in the victim dying, and low seriousness resulted in a quick trip to the emergency room and full recovery. High seriousness for the property offense resulted in destruction of the gas station, and low seriousness resulted in minimal damage that was easily repaired. We manipulated the premeditation of the crime by describing J.T.R. as happening upon a metal pipe that he or she used in the crime or taking a metal pipe from home in order to commit the crime described. For all of the vignettes, we included a statement that a woman in a nearby house saw the entire incident and called the police. The police then apprehended J.T.R. while he or she was running from the scene of the incident with the metal pipe that was used in the crime.

Perceptions of parental responsibility. Because of the known general versus specific variation in opinions (Applegate et al., 1996; Brank et al., 2004; Moon, Wright, Cullen, \& Pealer, 2000), we asked participants about both their general and specific attitudes toward parental responsibility. The questions were: "Parents are responsible when their child breaks the law" (general attitude) and "J.T.R.'s parents are responsible for the crime committed" (specific attitude). Respondents answered using a 1 to 5 scale, with 5 indicating "strongly agree." To capture the general versus specific variance, a difference score was calculated between the two questions for use as our dependent measure.

Procedure

Informed-consent forms and study materials were distributed to participants during three introductory statistics classes. The students completed the experiment during regular class time and took approximately 15 min to complete.

\section{Results and Discussion}

Overall, participants were significantly less likely to agree that J.T.R.'s parents were responsible for the crime $(M=2.23, S D=.86)$ than they were to agree that parents generally were responsible for juveniles' crimes, $M=2.78, S D=.99$. $t(245)=8.99, p<.01$. The mean responsibility difference score calculated from these two scores was .55.

Using the parental responsibility difference score as the dependent measure, we assessed the effects of the manipulated variables and found two significant main effects: age of described juvenile and type of offense. Participants viewed the parents of the 9-year-old as more responsible than parents of the 15-year-old, $F(1,238)=2.81, p<.10, \eta^{2}=.01$, and 
the parents of the juvenile who committed the personal injury offense as more responsible than parents of the juvenile who committed the property offense, $F(1,238)=40.48, p<.01$, $\eta^{2}=.03$. There was no main effect for prior record, seriousness of offense, race of the juvenile, premeditation, or juvenile's gender. No interaction effects available for analysis were significant. Accordingly, we decided to examine further the effects of offender age and nature of the crime in the subsequent studies and introduced differences in parental behavior as well.

\section{Study Two: Examining the Influence of Parental Behaviors on Beliefs about Responsibility}

In addition to assessing effects of the juvenile's age and type of crime committed on beliefs about parental responsibility, we manipulated the actions of the juvenile's parents, describing their actions as either omissions or commissions. To do so, we altered the experimental vignettes to suggest either that the parents left dangerous material where the juvenile could access them, or gave the child potentially hazardous materials - acts of omission and commission, respectively Because acts of commission generally garner stronger attributions of responsibility (Zeelenberg et al., 2000), we expected that the parents who were described as having committed (rather than omitted) actions would be seen as more responsible. In addition, we expected that the crime of personal injury would result in higher ratings of responsibility than a crime involving property damage, and that parents of younger juveniles would be seen as more responsible than parents of older juveniles.

\section{Methods}

Participants

We recruited participants $(n=142 ; 36 \%$ male; mean age $=20.58, S D=3.34)$ from two public universities, one in the Rocky Mountain region $(n=63)$ and the other in the southeast $(n=$ 79). The samples were not significantly different from each other on any demographic characteristics or variable of interest except that the sample from the southeastern university included more men (47\% vs. $22 \%$ ). Participants either volunteered with no compensation or received course credit in exchange for their participation.

The racial makeup of the sample was $81 \%$ White, 9\% Asian, $8.5 \%$ Hispanic/Latino, $6 \%$ Black, and 1\% other (totals more than $100 \%$ because participants could choose more than one category). We discarded responses from 25 participants who either did not complete the questionnaire or failed the manipulation check.

Design

Study Two used a 3 (juvenile's age) $\times 2$ (crime type) $\times 2$ (parents' actions) between-subjects experimental design to empirically investigate participants' beliefs about holding parents vicariously responsible in various situations. 


\section{Materials}

Scenario. We manipulated the juvenile's age $\left(9,13\right.$, or 17), ${ }^{2}$ the type of crime committed (personal injury or property damage), and the type of action by the parent (omission or commission). The omission condition depicted the juvenile taking either fireworks (in the property damage scenario) or an unlocked shotgun (in the personal injury scenario) from his parents' belongings. In both cases, the parents' act of omission was failing to secure those items. The commission scenario stated that the parents directly purchased the fireworks or shotgun for the juvenile. In both commission scenarios the parents' behavior was within legally permitted limits; the shotgun was described as being used for hunting and the fireworks were being used during a family holiday show. The property damage scenario described a juvenile who set the neighbor's shed on fire with the fireworks because of a dispute with the neighbor. In the personal injury scenario, the juvenile took a shotgun from home to settle an argument with a classmate and shot the classmate in the thigh, resulting in injuries that were not life-threatening. In both cases, the amount of damages was estimated to be $\$ 24,389$. Each scenario ended by saying that the juvenile's parents were shocked to learn about the incident. The vignettes were all approximately one page long.

Questionnaire. The questionnaire included demographic and manipulation check questions, and a question concerning attribution of responsibility for the incident. Specifically, participants assessed the percentage of responsibility of the child, his parents, his peers, society in general, and any other factors (See Hamilton, 1986). The total percentages were to add to $100 \%$.

Parental Locus of Control (PLOC) Parental Responsibility scale. To establish a measure that could control for notions of general parental responsibility, we adapted 10 questions from the Parental Responsibility subscale of the Parental Locus of Control (PLOC) scale (Campis, Lyman, \& Prentice-Dunn, 1986). Among the items were these: "There is no such thing as good or bad children - just good or bad parents," "A child's behavior problems are no one's fault but the parents'," and "Parents whose children make them feel helpless just aren't using the best parenting techniques." Respondents used a 5-point rating scale where 1 = strongly disagree and 5 = strongly agree. Higher scores reflected more agreement that parents are responsible for their child's behavior. Even with modifications of the subscale, Cronbach's alpha $(\alpha=.76)$ was comparable to that obtained by Campis et al. (1986) when they tested the scale in its original form (reported as $\alpha=.77, \mathrm{p} .261$ ).

Procedure

Participants were provided with consent forms and the questionnaire. They took between 25 and 40 min to complete the study. Administration was done both individually and in groups. 


\section{Results}

Parental Locus of Control

Our sample had a normal distribution on the PLOC Parental Responsibility subscale $(M=$ $3.08, S D=.44$ ) with no significant differences as a function of demographic characteristics, sample location, or manipulated variables. General PLOC Parental Responsibility scores were not influenced by variables of interest to this study.

\section{Responsibility Attributions}

Overall, participants placed the most responsibility on the juvenile described in the vignette $(M=53.17 \%, S D=21.13)$. Parents received the next highest percentage $(M=24.65 \%$, $S D=16.50)$. Participants held peers $(M=11.28 \%, S D=8.29)$ and society $(M=10.03 \%, S D=$ 7.54) similarly responsible. Very few participants indicated that there was another source of responsibility $(M=0.90 \%, S D=4.74)$.

Using the PLOC as a covariate and the percentage of responsibility assigned to parents as the dependent variable, we found main effects for all three manipulated variables. Participants saw the parents as more responsible when the juvenile committed a personal injury offense $(M=26.58 \%, S E=1.63)$ as opposed to a property offense $(M=20.34 \%$, $S E=$ $\left.1.70 ; F(1,132)=7.20, p<.01, \eta^{2}=.04\right)$, and when the scenario described a parental commission $(M=26.13 \%, S E=1.63)$ rather than an omission, $M=20.80 \%, S E=1.68 ; F(1,132)=5.42$, $p<.02, \eta^{2}=.03$. As expected, the parents were seen as more responsible when the juvenile was described as younger, but responsibility ratings for parents of the 13- and 17-year-olds were not significantly different, 9 years old: $M=28.40 \%, S E=1.91 ; 13$ years old: $M=21.98 \%$, $S E=2.04 ; 17$ years old: $M=20.02 \%, S E=2.09 ; F(2,132)=5.08, p<.01, \eta^{2}=.05$. Ratings of responsibility on the parent did not vary by respondents' gender. See Table 2 for the responsibility ratings for parents and juveniles.

\section{Discussion}

Case characteristics affected attributions of parental responsibility as measured by percent responsibility assigned to parents. As expected, parents who omitted actions that could have prevented the crime were seen as less responsible than parents who committed actions that led to the crime; personal injury offenses garnered higher ratings of parental responsibility than property crimes; and parents of 9-year-olds were deemed more responsible than parents of older youths. Because participants did not view parents of 13- and 17year-olds differently, we altered the age manipulations for Study Three to focus on just two more distinctly different ages.

These results support prior research showing that individuals are generally willing to place some responsibility on parents (Brank \& Weisz, 2004), though that effect is fairly weak. Overall, participants placed more than half the responsibility for the crime on the juvenile whereas the parents were deemed, on average, about $25 \%$ responsible. We next examined how parents of teenagers viewed the notion of parental responsibility and whether parental self-interest might influence their attitudes. 
Table 2. Nonparent Sample, Main Effects of Manipulated Variables and Respondents' Gender on Percent Responsibility (0-100\%) Attributions Placed on Parents and Juvenile

\begin{tabular}{|c|c|c|c|c|c|c|c|}
\hline & $M$ & $S E$ & $d f$ & MS & $F$ & $p$ & $\eta^{2}$ \\
\hline \multicolumn{8}{|c|}{ Responsibility placed on parents } \\
\hline \multicolumn{8}{|l|}{ Juvenile's age } \\
\hline 9 years old & 28.40 & 1.91 & & & & & \\
\hline 13 years old & 21.98 & 2.04 & 2,132 & 914.98 & 5.08 & $<.01$ & .05 \\
\hline 17 years old & 20.02 & 2.09 & & & & & \\
\hline \multicolumn{8}{|l|}{ Crime type } \\
\hline Personal injury & 26.58 & 1.63 & & & & & \\
\hline Property damage & 20.34 & 1.70 & 1,132 & 1298.06 & 7.20 & $<.01$ & .04 \\
\hline \multicolumn{8}{|l|}{ Action by parent } \\
\hline Omission & 20.80 & 1.68 & & & & & \\
\hline Commission & 26.13 & 1.63 & 1,132 & 976.41 & 5.42 & .02 & .03 \\
\hline \multicolumn{8}{|l|}{ Respondent's gender } \\
\hline Female & 25.18 & 1.45 & & & & & \\
\hline Male & 21.18 & 1.91 & 1,132 & 363.88 & 2.02 & .16 & .01 \\
\hline \multicolumn{8}{|c|}{ Responsibility placed on juvenile } \\
\hline \multicolumn{8}{|l|}{ Juvenile's age } \\
\hline 9 years old & 48.80 & 2.72 & & & & & \\
\hline 13 years old & 54.47 & 2.99 & 2,132 & 1518.53 & 4.17 & .02 & .05 \\
\hline 17 years old & 60.27 & 2.97 & & & & & \\
\hline \multicolumn{8}{|l|}{ Crime type } \\
\hline Personal injury & 51.12 & 2.41 & & & & & \\
\hline Property damage & 57.92 & 2.32 & 1,132 & 1541.87 & 4.23 & .04 & .03 \\
\hline \multicolumn{8}{|l|}{ Action by parent } \\
\hline Omission & 56.04 & 2.39 & & & & & \\
\hline Commission & 52.99 & 2.31 & 1,132 & 318.27 & .87 & .02 & .01 \\
\hline \multicolumn{8}{|l|}{ Respondent's gender } \\
\hline Female & 52.77 & 2.06 & & 379.38 & 1.04 & .31 & .01 \\
\hline Male & 56.26 & 2.71 & 1,132 & & & & \\
\hline
\end{tabular}

\section{Study Three: Examining the Influence of Parental Self-Interest}

The participants in Study Three were parents of teens or preteens. Our objective was to assess how case characteristics that we examined in Study Two would influence parents' notions of vicarious parental responsibility.

Attitudes about societal issues are often influenced by concerns of self-interest, especially when those issues can have immediate and adverse effects on respondents (Citrin \& Green, 1990). So, for example, when Crowe and Bailey (1995) questioned respondents about attitudes toward laws intended to reduce drunken driving, nondrinkers expressed more support than regular drinkers. When these researchers asked whether parents should be legally liable for the consequences of their children's underage drinking, parents of children under age 18 were less likely to say yes than were nonparents. Parents may have assigned less responsibility for reasons of self-interest; they might have felt personally vulnerable to the laws' mandates. 
We had another reason to suspect that parent-participants would be less likely than nonparents to hold parents answerable for children's misconduct. Because parents of teens have a better understanding of the complexities of child rearing (Ross \& Van Willigen, 1996) and of the multiple factors that influence a juvenile's decision to commit a crime, including factors that are outside of a parent's control, they would be less likely than nonparents to hold parents responsible.

Study Three used the same materials as in Study Two, though we described the juvenile as either 10 or 16 years old. We hypothesized that the personal injury case would garner more parental responsibility than the property crime, that acts of commission would result in higher attributions of parental responsibility than acts of omission, and that the younger the child, the more responsibility would be attributed to the parents. We also expected to find lower levels of responsibility attributed to parents than in Study Two.

\section{Methods}

\section{Participants}

Parents $(n=118)$ of middle school and high school students attending a university laboratory school participated in this study. Twenty-one percent were male. The mean age was 44.22 years $(S D=6.44)$. The majority $(75 \%)$ was White, $20 \%$ were Black, $8 \%$ Hispanic/Latino, 2\% American Indian/Native Alaskan/Hawaiian, 1\% Asian, and $4 \%$ other (totals more than $100 \%$ because participants could choose more than one category). Participants had on average 2.59 children with most (68\%) having two or three children (maximum reported was 6). Participants were mailed $\$ 10$ when their questionnaires were completed and returned. The sample does not include participants we removed because of missing values $(n=3)$ and incorrect manipulation check answers $(n=1)$.

Design

This study used a 2 (juvenile's age) $\times 2$ (parental action) $\times 2$ (crime type) between-subjects experimental design to empirically investigate the attributions of responsibility by parents of middle school and high school students.

\section{Materials}

Scenario. This study used the same core scenarios and questionnaires as in the previous study with the juvenile described as either 10 or 16, the type of crime being personal injury or property damage, and the type of action by the parent being either an omission or commission.

Questionnaire. In addition to the questions used previously (i.e., attributions of responsibility, demographics, manipulation checks, parental locus of control), we asked demographic questions that related specifically to parents (e.g., number of children) and their knowledge of parental responsibility laws. 
Foreseeability. We also asked participants whether they agreed with the following statement: "In this incident, the juvenile's parents should have foreseen the consequences of their actions" $(1=$ strongly disagree to $5=$ strongly agree $)$. The notion of foreseeability goes beyond responsibility and speaks to the preventability of the act.

Appropriateness of legal outcomes. After explaining the various types of parental responsibility laws, we asked participants to rank the appropriateness of different legal responses to the crime. The options were (a) the victim brings a civil case against the parents; (b) the state charges the parents with contributing to the delinquency of a minor; (c) the state requires the parents to be involved in adjudication (the general involvement statutes described above); or (d) nothing happens to the parents. Participants indicated how much money damages they thought should be awarded to the victim who sued in a civil case. They also selected a level of severity for each of several sanctions associated with the crime of contributing to the delinquency of a minor. The options were (a) imprisonment ranging from none to 10 years or more; (b) a fine ranging from $\$ 0$ to $\$ 25,000$ or more; (c) community service ranging from 0 hours to 100 hours or more; (d) probation ranging from 0 years to 5 years or more; and (e) no sanctions. To address the requisite knowledge component for a contributing to the delinquency case, we also asked participants, "Did the juvenile's parents knowingly contribute to his delinquent behavior in this incident?" Response options were yes or no. Participants also ranked the appropriateness of seven parental involvement options (where $1=$ least appropriate and $7=$ most appropriate) including (a) participate in court proceedings; (b) attend parenting classes; (c) participate in community service; (d) pay victim restitution; (e) pay detention costs; (f) attend counseling; and (g) no sanctions.

\section{Procedure}

Materials were sent home from school with students attending a university laboratory middle or high school. We requested that the parent who had most recently celebrated a birthday complete and return the questionnaire. Reminder letters were sent home with students one week after the initial packets were distributed. Five hundred forty-eight study packets were distributed, and 118 usable questionnaires were returned (response rate of $22 \%$ ); however, that rate may be artificially low because some of the packets likely did not make it into parents' hands.

\section{Results}

Parental Locus of Control

Similar to Study Two, the sample had a normal distribution on the PLOC $(\alpha=.70)(M=3.30$, $S D=.48)$ with no significant differences as a function of demographic characteristics, knowledge of laws, or manipulated variables.

\section{Responsibility Attributions}

As in Study Two, parent-participants placed the greatest responsibility on the juvenile $(M=47.59 \%, S D=23.41)$. The juvenile's parents received the next highest percentage $(M=36.88 \%, S D=22.59)$ with society $(M=7.44 \%, S D=7.67)$ and peers $(M=7.12 \%, S D=6.87)$ 
viewed similarly. Only a very few people indicated there were other sources of responsibility $(M=0.91 \%, S D=3.64)$.

Using the percentage of responsibility assigned to parents as the dependent variable and scores on the PLOC as a covariate, we found only one significant main effect for the manipulated variables: the age of the juvenile (10 years old: $M=44.79 \%, S E=2.54 ; 16$ years old $M=26.03 \%, S E=2.75$ ) resulted in significantly different responsibility attributions toward the parents, $F(1,110)=24.79, p<.01, \eta^{2}=.15$. As displayed in Table 3, neither the manipulation of parental omission versus commission, $F(1,110)=1.43, p=.23, \eta^{2}<.01$, nor the type of crime committed, $F(1,110)=2.55, p=.11, \eta^{2}=.02$, affected attributions of responsibility toward the parents. In contrast to the student sample, there was a main effect for respondents' gender such that mothers rated the parents as more responsible $(M=37.80 \%$, $S E=1.96)$ than did fathers, $M=26.13 \%, S E=3.9 ; F(1,110)=7.06, p<.01, \eta^{2}=.04$.

Table 3. Parent Sample, Main Effects of Manipulated Variables and Respondents' Gender on Percent Responsibility Attributions Placed on Parents and Juvenile

\begin{tabular}{|c|c|c|c|c|c|c|c|}
\hline & $M$ & $S E$ & $d f$ & MS & $F$ & $p$ & $\eta^{2}$ \\
\hline \multicolumn{8}{|c|}{ Responsibility placed on parents (0-100 \%) } \\
\hline \multicolumn{8}{|l|}{ Juvenile's age } \\
\hline 10 years old & 40.90 & 2.73 & & & & & \\
\hline 16 years old & 23.02 & 2.90 & 1,110 & 8488.82 & 24.79 & $<.01$ & .15 \\
\hline \multicolumn{8}{|l|}{ Crime type } \\
\hline Personal injury & 29.15 & 2.74 & & & & & \\
\hline Property damage & 34.78 & 2.85 & 1,110 & 873.74 & 2.55 & .11 & .02 \\
\hline \multicolumn{8}{|l|}{ Action by parent } \\
\hline Omission & 29.89 & 2.78 & & & & & \\
\hline Commission & 34.04 & 2.78 & 1,110 & 490.89 & 1.43 & .23 & $<.01$ \\
\hline \multicolumn{8}{|l|}{ Respondent's gender } \\
\hline Female & 37.79 & 1.96 & & & & & \\
\hline Male & 26.13 & 3.90 & 1,110 & 2418.69 & 7.06 & $<.01$ & .04 \\
\hline \multicolumn{8}{|c|}{ Responsibility placed on juvenile (0-100\%) } \\
\hline \multicolumn{8}{|l|}{ Juvenile's age } \\
\hline 10 years old & 44.53 & 2.84 & & & & & \\
\hline 16 years old & 60.78 & 3.02 & 1,110 & 7017.57 & 19.00 & $<.01$ & .12 \\
\hline \multicolumn{8}{|l|}{ Crime type } \\
\hline Personal injury & 52.87 & 2.85 & & & & & \\
\hline Property damage & 52.44 & 2.96 & 1,110 & 5.08 & .01 & .91 & $<.01$ \\
\hline \multicolumn{8}{|l|}{ Action by parent } \\
\hline Omission & 54.78 & 2.89 & & & & & \\
\hline Commission & 50.54 & 2.88 & 1,110 & 511.71 & 1.39 & .24 & .01 \\
\hline \multicolumn{8}{|l|}{ Respondent's gender } \\
\hline Female & 46.52 & 2.03 & & & & & \\
\hline Male & 58.79 & 4.05 & 1,110 & 2680.25 & 7.25 & $<.01$ & .05 \\
\hline
\end{tabular}

Foreseeability

Participants generally agreed that the parents should have foreseen the delinquent activity described in the vignette $(M=3.68, S D=1.07)$. There was a significant positive correlation between foreseeability and percent of responsibility placed on parents $(r=.45, p<.01)$ and 
a significant negative correlation between foreseeability and percent of responsibility placed on the juvenile $(r=-.44, p<.01)$.

Using foreseeability as the dependent variable and scores on the PLOC Parental Responsibility subscale as a covariate, only the age of the described juvenile had a significant main effect. $F(1,108)=5.03, p=.03, \eta^{2}=.04$, with the 10-year-old's actions seen as more foreseeable $(M=3.76, S E=.15)$ than those of the 16-year-old $(M=3.30, S E=.16)$. As seen in Table 4 , there were no other significant main effects of the manipulated variables or of respondents' gender.

Table 4. Parent Sample, Main Effects of Manipulated Variables and Respondents' Gender on Perceived Foreseeability of Delinquent Behavior

\begin{tabular}{|c|c|c|c|c|c|c|c|}
\hline & $M$ & $S E$ & $d f$ & MS & $F$ & $p$ & $\eta^{2}$ \\
\hline \multicolumn{8}{|c|}{ Responsibility placed on parents $(0-100 \%)$} \\
\hline \multicolumn{8}{|l|}{ Juvenile's age } \\
\hline 10 years old & 3.76 & .15 & & & & & \\
\hline 16 years old & 3.31 & .16 & 1,108 & 5.36 & 5.03 & .03 & .04 \\
\hline \multicolumn{8}{|l|}{ Crime type } \\
\hline Personal injury & 3.49 & .15 & & & & & \\
\hline Property damage & 3.58 & .16 & 1,108 & .188 & .18 & .68 & $<.01$ \\
\hline \multicolumn{8}{|l|}{ Action by parent } \\
\hline Omission & 3.44 & .16 & & & & & \\
\hline Commission & 3.63 & .16 & 1,108 & 1.01 & .95 & .33 & .02 \\
\hline \multicolumn{8}{|l|}{ Respondent's gender } \\
\hline Female & 3.70 & .11 & & & & & \\
\hline Male & 3.37 & .22 & 1,108 & 1.99 & 1.87 & .18 & .02 \\
\hline
\end{tabular}

Note: Foreseeability (1 strongly disagree; 5 strongly agree)

Knowledge of Laws and Appropriateness of Legal Outcomes

When asked whether they had heard of parental responsibility laws before beginning the questionnaire, $64 \%$ of participants reported that they had. We asked respondents to consider four potential consequences for the juvenile's parents: the victim brings a civil case against the parents; the parents are charged with contributing to the delinquency of a minor; the parents are required to be involved in adjudication; or nothing (see Table 1). Each option was explained, and respondents ranked the possible outcomes' appropriateness. The highest-ranking option was the involvement option; $71 \%(n=77)$ of parents indicated that this option was most appropriate. All other options were deemed much less appropriate: the victim brings a civil case was ranked as most appropriate by $15 \%(n=16)$, the parents are charged with contributing to delinquency was ranked most appropriate by $12 \%,(n=13)$, and the option to "do nothing" was ranked most appropriate by $3 \%(n=3)$. Our sample size combined with the number of manipulated variables and possible case outcomes precludes us from examining manipulated case characteristics (e.g., age of described juvenile) with all outcome options.

Civil case. Despite the fact that few respondents favored this option in our initial question about appropriate outcomes, the vast majority of our sample (91\%) indicated that if the 
victim brought a civil parental liability case, they would award damages. The description indicated that the victim was claiming $\$ 24,389$ in damages. On average, participants who said they would award damages provided an amount similar to that figure $(M=\$ 23,280$, $S D=\$ 4,402)$.

Contributing to the delinquency of a minor case. Participants were divided on whether the juvenile's parents "knowingly contributed to his delinquent behavior" with 51\% $(n=60)$ saying they did. When the juvenile was described as a 10 -year-old, significantly more participants $(70 \%)$ believed the parents had contributed to his behavior than when the juvenile was described as a 16-year-old, $30 \% ; \chi^{2}(N=118)=7.65, p<.01, \varphi=.09$. Participants rated the contribution of parents to the juvenile's delinquency as greater with the parents' commission than with their omission, $60 \%$ and $40 \%$, respectively, $\chi^{2}(N=118)=4.08, p<.05$, $\varphi=.06$. Neither the type of case described (i.e., personal injury vs. property damage), nor the respondents' gender influenced whether they saw the parents as contributing to the delinquency.

When asked about potential sanctions for contributing to the delinquency of a minor, almost half indicated that the parents should receive no sanctions (48\%). The other half indicated varying levels of support for other sanctions (they could endorse more than one). Imprisonment of the parents was not a popular option with only $9 \%$ indicating that it was appropriate. Thirty-four percent thought probation was an appropriate option, $47 \%$ thought a fine was appropriate, and $49 \%$ thought community service was appropriate.

Parental involvement options. Participants were asked to rank the appropriateness of seven options for parental involvement. The following percentages are for the participants who used the 1-7 ranking system as instructed and used each number only once. Pay victim restitution garnered the greatest support (51\% said it was most appropriate). There was much less support for other options: no sanctions, $12 \%$; participate in court proceedings, $12 \%$; attend counseling, $12 \%$; attend parenting classes, $6 \%$; pay detention costs, $3 \%$; and participate in community service, $2 \%$. Our sample size combined with the number of manipulated variables and possible parental involvement options precludes us from examining manipulated case characteristics (e.g., age of described juvenile) with all sanction options.

\section{Discussion}

As in Study Two, participants assigned the largest share of responsibility for these crimes $(48 \%)$ to the juvenile and less responsibility to the parents (37\%). Mothers placed more responsibility on the juvenile's parents than did fathers (38\% vs. $26 \%$ ). Surprisingly, parentparticipants attributed more responsibility to the described parents than did nonparentparticipants in Study Two (37\% vs. 25\%). Perhaps parents of teens (especially mothers) level some responsibility on other parents because through various self-serving biases, they come to believe that they would not have acted in a similar manner. Hence, it may be easier to demean other parents by holding them responsible. It is also possible that because parental responsibility laws are infrequently enforced, few parents would feel vulnerable to their sanctions. If this is the case, then their responses would not be influenced by any 
self-interest, and they would be free to impose accountability on parents as they wish. Another possible explanation is that the parents who responded to our questionnaire may be more involved in their children's lives and more responsible generally and therefore may be more inclined to hold other parents responsible when negative events occur.

In deciding whether parents are responsible for the delinquent acts of their child, parentparticipants focused on the age of the juvenile; they deemed parents of a 10-year-old more responsible than parents of a 16-year-old. Contrary to our hypotheses and in contrast to findings from Study Two, ratings of parental responsibility were not influenced by the type of crime committed by the juvenile or the parental actions that preceded the crime.

We also asked whether the parents should have foreseen the juvenile's crime because, presumably, foreseeable acts can be prevented. Although parent-participants generally thought the described parents should have foreseen the crime, only the manipulated age of the juvenile had an effect on foreseeability ratings. The foreseeability of the crime was not dependent on whether the described parents had committed an act (i.e., giving the juvenile a gun) or omitted an act (i.e., failing to lock up their gun), or on whether the crime resulted in personal injury or property damage.

Most participants thought that there should be some sort of sanction on the parents, but very few thought that the intervention should be a classic punitive response (e.g., imprisonment). For the most part, participants focused on restorative goals: they wanted the parents to be involved in the child's adjudication in order to provide the victim with restitution and obtain counseling with the young offender. Such responses demonstrate that participants were less concerned with punishing the parents than with ensuring that some good come from the incident.

\section{General Discussion}

Responsibility can arise absent direct causation when a person is answerable for the actions of another who directly causes the harm. For example, employers are answerable (in tort law, "vicariously liable") for the acts of employees within the scope of employment. Similarly, parents are broadly answerable for the behavior of their children. The questions we address here concern the public's views on parents' legal responsibility.

Our intent was to assess how people attribute responsibility to parents for the actions of their children. We were interested in how they consider the circumstances related to the harm, and whether their status as parents (vs. nonparents) affects their beliefs. The specific questions we addressed were these: Is it reasonable to ascribe responsibility to parents who neither caused a harmful act nor could foresee it? Does it matter whether the child who caused the harm is younger and impressionable or older and independent? Does it matter whether the child caused physical injury to another person or destroyed property? Should parents' acts of omission be deemed comparable to acts of commission, as parental responsibility statutes require?

We found that overall, the largest share of responsibility for juvenile crime rests with the juvenile offender, but that observers attribute some responsibility to parents as well. The readiness to hold parents responsible varied as a function of situational variables, 
notably the age of the child. Parents of younger youth were judged more responsible for their child's criminal conduct than parents of older youth.

According to vicarious responsibility theory and previous research (e.g., Shultz et al., 1987) for one individual to be held responsible for the actions of another, the first individual must have control over or be in a superior social situation to the actor. Though parents are assumed to be in a superior position to their children, the age of the child influences the control parents can exert. It is a commonly held belief that the younger the child, the more influence his or her parents wield, and the less social standing the child has. The bond between parenting behavior and a child's actions weakens as a child ages (Tomaszewski, 2005). The attenuated relationship between parents' control and older teens' behaviors, combined with the fact that older teens are more likely than younger teens to engage in acts of delinquency, apparently makes parental responsibility laws seem relatively ineffectual as applied to parents of older children.

Whereas parental responsibility statutes make no distinction between parents' acts of omission and commission and hold parents accountable regardless of the nature of the conduct that led to the transgression, people typically view these circumstances differently. They perceive that outcomes emanating from acts of omission are less predictable and thus less intentional than outcomes that follow from acts of commission. Thus, we expected to find higher levels of responsibility assigned to parents who actively committed an act that led to the crime than to parents who passively omitted an act.

Nonparent-participants responded this way, but parent-participants showed no differences in attributions of responsibility to the described parents as a function of their conduct. Perhaps the experience of parenting teens enhances one's ability to anticipate consequences of their and others' actions. In essence, through their own experiences, the parents come to realize that leaving a weapon or fireworks accessible invites their use by teen and preteen children as directly as does actually providing those objects to their children. To their minds, the described parents who failed to act should have known better. A possible area of future work would be to compare in more depth parents who have younger versus older children and parents who have juveniles who have been charged or found delinquent versus juveniles who have not. We expect that these differences in parenting experiences would influence opinions of other parents' responsibility.

There are several limitations to the current set of studies. First, although vignette methodology presents a richer set of contextual information than survey methodology, that information is nonetheless an abbreviated synopsis. With more detail about the child, the parents, and the nature of their home life and relationship, respondents' assessments of the parents' responsibility may be somewhat different. Second, although we probed respondents' thoughts about the foreseeability of the crime, our findings would have been enhanced by asking about other criteria related to accountability, including the extent to which parents could control the outcome, had justification for their conduct, coerced the child, and desired the outcome, and the extent to which the crime was causally connected to their actions. Third, we acknowledge that asking laypeople to make criminal and civil judgments was problematic given that they had little instruction, few guidelines, and essentially no experience. Finally, we used a college student sample in our first two studies to determine the manipulated factors in Studies Two and Three; had we used a more 
diverse sample initially, we may have chosen to examine different factors for our later studies. These findings should be interpreted cautiously.

We have been careful to distinguish the concept of responsibility from those of causation, blame, and guilt. Parental responsibility laws make parents accountable even in situations where their actions were not the primary cause of an offense and in which they were neither legally blameworthy nor factually guilty. Although the general public often conflates these concepts (Hamilton, 1978), they are different constructs (Mantler, Schellenberg, \& Page, 2003) and should not be used synonymously (Gailey \& Lee, 2005). Still, we believe there may be some merit in borrowing concepts from Alicke's (2000) culpable control theory of blame assessments to understand why people are willing to attribute at least some responsibility to parents.

The essence of Alicke's theory is that the desire to hold an actor accountable skews people's perception of the degree to which that actor controlled the outcome. Especially in situations where a victim is grievously injured by a young person who is unable to provide any meaningful compensation, observers may cast around for other sources of wrongdoing and potentially deeper pockets. Parents are obvious targets. By inferring that a child's parents had some control-however tenuous - of the outcome, observers can justify their attributions of responsibility on the parents.

But despite people's willingness to impose some responsibility on parents, they still hold the child most accountable for a wrongdoing, and nonparent respondents were even less likely than parent respondents to assign responsibility to parents of an errant child. We suspect that our respondents' disapproval of complete vicarious parental responsibility may reflect one reason the laws have not been widely enforced.

Regarding enforcement, Harris (2006) surveyed police chiefs and prosecutors in Oregon and asked them, among other things, how often they issued citations and prosecuted these cases. ${ }^{3}$ She found that in nearly three fourths of the Oregon communities in her sample, parents were never cited for violations of parental responsibility laws. In most of the remaining communities, citations were issued only occasionally (4-11 times per year) and in only two towns did police chiefs cite more than 20 times per year. Prosecutions were also rare: nearly $80 \%$ of district attorneys said they rarely or never prosecuted parents for violating these ordinances.

There are undoubtedly multiple explanations for the lack of enforcement, including insufficient resources for law enforcement personnel, their perception that the laws lack "teeth," and little reason to believe that they serve as a deterrent. Harris (2006) suspects that these laws are largely symbolic and that their purpose is to shape parenting norms and convey a message about acceptable parenting practices. Our data suggest that lack of enforcement may also derive from the fact that the public is, at best, lukewarm to the idea of making parents answerable for the actions of their children. We suspect that in the minds of many, parents' actions constitute a crucial component of healthy development yet cannot sufficiently explain delinquency and holding parents responsible for their child's conduct will do little to remedy the problem of juvenile crime. 
Acknowledgments - This research was supported by a grant from the Society for the Psychological Study of Social Issues (SPSSI). Portions of this research were done in partial fulfillment of K. H.'s master's degree requirements. The authors would like to acknowledge Christine Driver, Stephanie Hays, and Megan Mocko for their help with the project.

\section{Notes}

1. We removed parents from the sample because we wanted to keep our initial sample as homogeneous as possible.

2. A 17-year-old is considered a minor in every state in the United States (unless there has been an emancipation decision), and thus his or her parents are subject to parental responsibility laws.

3. The Oregon legislature enacted a statewide statute in 1995 which falls under the "contributing to the delinquency of a minor" category; OR. REV. STAT. § 163.577(1)(a)-(c) (2003); originally enacted as 1995 Or. Laws 1544, ch. 503, § 1. In addition, numerous communities in Oregon have enacted local parental responsibility laws (Harris, 2006).

\section{References}

Alicke, M. (1992). Culpable causation. Journal of Personality and Social Psychology, 63, 368-378. doi:10.1037//0022-3514.63.3.368

Alicke, M. (2000). Culpable control and the psychology of blame. Psychological Bulletin, 126, 556-574. doi:10.1037//0033-2909.126.4.556

Applegate, B. K., Cullen, F. T., Turner, M. G., \& Sundt, J. L. (1996). Assessing public support for threestrikes-and-you're-out laws: Global versus specific attitudes. Crime and Delinquency, 42, 517-534. doi:10.1177/0011128796042004002

Brank, E. M., Hays, S. A., \& Weisz, V. (2004). All parents are to blame (Except this one): Global versus specific attitudes related to parental responsibility law. Journal of Applied Social Psychology, 36, 2670-2684. doi:10.1111/j.0021-9029.2006.00122.x

Brank, E. M., Kucera, S. C., \& Hays, S. A. (2005). Parental responsibility statutes: An organization and policy implications. Journal of Law and Family Studies, 7, 1-55.

Brank, E. M., \& Lane, J. (2008). Punishing my parents: Juveniles' perspectives on parental responsibility, Criminal Justice Policy Review, 19, 333-348. doi:10.1177/0887403407311956

Brank, E. M., \& Weisz, V. (2004). Paying for the crimes of their youth: Public support of parental responsibility laws. Journal of Criminal Justice, 32, 465-475. doi:10.1016/ j.jcrimjus.2004.06.010

Campis, L. K., Lyman, R. D., \& Prentice-Dunn, S. (1986). The parental locus of control scale: Development and validation. Journal of Clinical Child Psychology, 15, 260-267. doi:10.1207/s15374424 jccp1503_10

Cartwright, W. (2006). Responsibility: A puzzle, two theories, and bad background. Philosophy, Psychiatry, \& Psychology, 13, 167-176. doi:10.1353/ppp.2007.0004

Citrin, J., \& Green, D. (1990). The self-interest motive in American public opinion. Research in Micropolitics, 3, 1-27. doi:10.1086/269185

Crowe, J., \& Bailey, W. (1995). Self-interest and attitudes about legislation controlling alcohol. Psychological Reports, 76, 995-1003.

Curfew for minors. (2009). Wilmington, DE Article IV, § 36-97, Offenses involving public morals. 
Davies, H. J., \& Davidson, H. A. (2001). Parental involvement practices of juvenile courts. Washington, DC: American Bar Association.

Denson, T. F., Lickel, B., Curtis, M., Stenstrom, D. M., \& Ames, D. R. (2006). The roles of entitativity and essentiality in judgments of collective responsibility. Group Processes and Intergroup Relations, 9, 43-61. doi:10.1177/1368430206059857

Feinberg, J. (1968). Action and responsibility. In A. R. White (Ed.), The philosophy of action (pp. 95119). Oxford, U. K.: Oxford University Press.

Fincham, F. D., \& Jaspars, J. M. (1980). Attribution of responsibility: From man the scientist to man as lawyer. In L. Berkowitz (Ed.), Advances in experimental social psychology (Vol. 13, pp. 81-138). New York: Academic Press.

Frankena, W. K. (1963). Ethics. Saddle River, NJ: Prentice Hall.

Gailey, J. A., \& Lee, M. T. (2005). An integrated model of attribution of responsibility for wrongdoing in organizations. Social Psychology Quarterly, 68, 338-358. doi: 10.1177/019027250506800403

Ghetti, S., \& Redlich, A. D. (2001). Reactions to youth crime: Perceptions of accountability and competence. Behavioral Sciences and the Law, 19, 33-52. doi:10.102/bsl.426

Graffiti prohibited. (2009). Jacksonville, FL § 614.140, Public order and safety.

Greene, E., \& Darley, J. (1998). Effects of necessary, sufficient, and indirect causation on judgments of criminal liability. Law and Human Behavior, 22, 429-451. doi: 10.1023/A:1025723010408

Hamilton, V. L. (1978). Who is responsible? Toward a social psychology of responsibility attribution. Social Psychology, 41, 316-328. doi:10.2307/3033584

Hamilton, V. L. (1986). Chains of command: Responsibility attribution in hierarchies. Journal of Applied Social Psychology, 16, 118-138. doi:10.1111/j.1559-1816.1986.tb02283.x

Harris, L. J. (2006). An empirical study of parental responsibility laws; Sending messages, but what kind and to whom? Utah Law Review, 2006, 5-34.

Heider, F. (1958). The psychology of interpersonal relations. New York: Wiley.

Ihrie, A. D. (1996). Parental delinquency: Should parents be criminally liable for failing to supervise their children? University of Detroit Mercy Law Review, 74, 93-112.

Kordes-de Vaal, J. H. (1996). Intention and the omission bias: Omissions perceived as nondecisions. Acta Psychologica, 93, 161-172. doi:10.1016/0001-6918(96)00027-3

Leonard, K., Pope, C., \& Feyerherm, W. (Eds.). (1995). Minorities in juvenile justice. Thousand Oaks, CA: Sage.

Lickel, B., Schmader, T., \& Hamilton, D. L. (2003). A case of collective responsibility: Who else was to blame for the Columbine High School shootings? Personality and Social Psychology Bulletin, 29, 194-204. doi:10.1177/0146167202239045

Mantler, J., Schellenberg, E. G., \& Page, J. S. (2003). Attributions for serious illness: Are controllability, responsibility, and blame different constructs? Canadian Journal of Behavioural Science, 35, 142-152. doi:10.1037/h0087196

Moon, M. M., Wright, J. P., Cullen, F. T., \& Pealer, J. (2000). Putting kids to death: Specifying public support for juvenile capital punishment. Justice Quarterly, 17, 663-684. doi:10.1080/07418820000094711

Mustard, D. (2001). Racial, ethnic, and gender disparities in sentencing: Evidence from the U.S. Federal Courts. Journal of Law and Economics, 44, 285-314. doi: 10.1086\%2F320276

Page, B. I., \& Shapiro, R. Y. (1983). Effects of public opinion on policy. The American Political Science Review, 77, 175-190. doi:10.2307/1956018 
Parental duties. (2009). Detroit, MI. Article VI, § a1946-1. Parental responsibility. Public Agenda Online. (1999). Kids these days. Retrieved from http://www.publicagenda.org/specials/kids/kids 3d.htm

Restraint required. (2009). Indian Shores, FL, Article 22, §14-31, Care and Control.

Roberts, J. V. (1997). The role of criminal record in the sentencing process. Crime and Justice, 22, 303362. doi:10.1086/449265

Ross, C. E., \& Van Willigen, M. (1996). Gender, parenthood and anger. Journal of Marriage and Family, 58, 572-584. doi:10.2307/353718

Samuel, W., \& Mould, E. (1986). The effect of crime severity on perceptions of fair punishment: A California case study. The Journal of Criminal Law \& Criminology, 77, 931-948. doi:10.2307/1143444

Sanders, J., \& Hamilton, V. L. (1987). Is there a "common law" of responsibility? The effect of demographic variables on judgments of wrongdoing. Law and Human Behavior, 11, 277-297. doi:10.1007/BF01044742

Schlenker, B. R., Britt, T. W., Pennington, J. W., Murphy, R., \& Doherty, K. J. (1994). The triangle model of responsibility. Psychological Review, 101, 632-652. doi:10.1037/0033-295X.101.4.632

Shultz, T. R., Jaggi, C., \& Schleifer, M. (1987). Assigning vicarious responsibility. European Journal of Social Psychology, 17, 377-380. doi:10.1002/ejsp.2420170314

Simourd, L., \& Andrews, D. (1994). Correlates of delinquency: A look at gender differences. Forum on Corrections Research, 6, 26-31.

Spranca, M., Minsk, E., \& Baron, J. (1991). Omission and commission in judgment and choice. Journal of Experimental Social Psychology, 27, 76-105. doi:10.1016/0022-1031(91)90011-T

Stolle, D. P., Robbennolt, J. K., Patry, M., \& Penrod, S. D. (2002). Fractional factorial designs for legal psychology. Behavioral Sciences and Law, 20, 5-17. doi:10.1002/bsl.475

Tomaszewski, A. (2005). From Columbine to Kazaa: Parental liability in a new world. University of Illinois Law Review, 2005, 573-599.

Tyler, J. E., \& Segady, T. W. (2000). Parental liability laws: Rationale, theory, and effectiveness. Stephen F. Austin State University, 37, 79-96. doi:10.1016/S0362-3319(99)00064-6

Tyler, T. R. (2006). Why people obey the law. Princeton, NJ: Princeton University Press.

Warr, M., Meier, R. F., \& Erickson, M. L. (1983). Norms, theories of punishment, and publicly preferred penalties for crimes. Sociological Quarterly, 24, 75-91. doi:10.1111/j.1533-8525.1983.tb02229.x

White, N. (2005). Attribution and mitigation of parent and child responsibility: A qualitative analysis. Psychiatry, Psychology, and Law, 12, 401-410. doi:10.1375/pplt.12.2.401

White, N., Augoustinos, M., \& Taplin, J. (2007). Parental responsibility for the illicit acts of their children: Effects of age, type and severity of offence. Australian Journal of Psychology, 59, 43-50. doi:10 $.1080 / 00049530600944374$

Zeelenberg, M., van der Pligt, J., \& de Vries, N. K. (2000). Attributions of responsibility and affective reactions to decision outcomes. Acta Psychologica, 104, 303-316. doi:10.1016/S0001-6918(00)00034-2 